\title{
Image of an animal in outlook of nomads: results of the expedition in the territory of Abay Region of East Kazakhstan oblast ${ }^{1}$
}

\author{
Umitkaliyev Ulan Umitkaliuly \\ Candidate of History, Associate professor, Head of the Department of Archeology and Ethnology of \\ Euroasian National University.
}

Abstract. The results of the research of the Department of Archeology and Ethnology of L.N. Gumilev Euroasian National University which is carried out on the basis of the archaeological research executed in a complex monument "Kyryk ungir" in the settlement of Toktamys of Abay Region in East Kazakhstan oblast are shown in this article. The main objective of an expedition consisted in conducting archaeological investigation of the east part of the lowland of Sary-arka and also in the analysis of the results of archeological excavations on monuments of Bronze and the early Iron Age, the description of the objects, mapping, studying of features of petroglyphs in the region. Besides, the evidential conclusions on the historical heritage of this region, in which there are the great cultures of Mountain Altay and Sary-arka, are drawn in the article.

We will notice that the research wasn't limited by archeological excavations. Works on studying of petroglyphs in the region, to collecting fresh data on local traditions and toponymic data wereconducted in parallel. At the same time one more aspect of the research consisted in focusing on studying of fundamentals of the national economy and differentiation outlook of the population. As a result of an expedition the list of ancient monuments of the Iron Age from the early Iron Age on the region has been made. 5 objects of the early Iron Age have been investigated. The monument of the early Iron Age and also bronze mirrors, stone beads and clay vessels have been found, the comparison of finds with results of studying of adjacent regions is carried out.

Key words: Kyryk ungir; Shilikty; Taldy I; Taldy II; Karakemer; environment; rock paintings; image of cat family; hunting.

\section{Көшпелілер дүниетанымындағы аң бейнесі: Шығыс Қазақстан облысы, Абай ауданы территориясына жасалған экспедицияның қорытындылары ${ }^{2}$}

\section{Үмітқалиев Ұлан Үмітқалиұлы}

тарих ғылымдарының кандидаты, доцент, Л.Н. Гумилев атындағы Еуразия Ұлттық Университеті археология және этнология кафедрасының меңгерушісі.

Абстракт. Аталмыш мақалада Л.Н. Гумилев атындағы Еуразия ұлттық университетінің археология және этнология кафедрасының ғалымдары зерттеуімен Шығыс Қазақстан облысы, Абай ауданындағы Тоқтамыс елді мекеніне қарасты Қырықүңгір кешенді ескерткішінде жүргі зілген археологиялық зерттеу жұмыстарының қорытындылары негізінде ғылыми сараптамалар жасалады.

Экспедицияның негізгі мақсаты болып, қазақтың ұсақ шоқылығы болып келетін шығыс Сарыарқа өңіріне археологиялық барлау жұмыстарын жүргізу, қола және ерте темір дәуірлеріне жататын ескерткіштерге археологиялық қазба жұмыстарын жүргізу, нысандардың сипаттамасын жасау, картаға түсіру, өңірдегі петроглифртердің ерекшеліктерін зерделеу еді. Сонымен қатар ғылымда Таулы Алтайдың және кең жазиралы Сарыарқаның үлкен мәдениеттерін ұштастыратын бұл өлкедегі тарихи мұралар арқылы салмақты тұжырымдар жасау.

Зерттеу жұмыстары тек археологиялық қазба жұмыстарымен шектелмей, өңірдегі петроглифтерді зерттеумен, жергілікті жердің жер-су аттары мен халықтың әдет ғұрып салт-санасына қатысты тың деректер жинау болды. Сонымен бірге зерттеудің келесі бір бағыты халықтың негізгі шараушылығына терең мән беріп соған қатысты дүниетанымдық түсініктерді саралау болды.

Экспедицияның нәтижесінде үш жылдың көлемінде өңірден ерте темір дәуіріне жататын 70ке тарта ерте темір дәуірінің ескерткіштері тізімге алынып төлқұжаты жасалынды.Соның ішінде ерте темір дәуірінің 5 нысаны зерттеліп, ғылыми қорытынды жасалды. Зерттеу барысында табылған ерте темір дәуіріне жататын аң бейнесі мен бірге қола айна мен тас моншақтар және қышы ыдыстар көршілес аймақтардың табылымдарымен салыстырылып қарастырылды.

\footnotetext{
${ }^{1}$ The study was carried out within the framework of the project «Development of research work on archeology in the East Kazakhstan region»

2 Зерттеу жұмысы «Шығыс Қазақстан облысында археология саласында ғылыми-зерттеу жұмыстарын дамыту» жобасының аясында орындалған
} 
Түйін сөздер: Қырықүңгір; Шілікті; Талды I; Талды II; Қаракемер,табиғи орта; жартас суреттері; мысық тұқымдастар бейнесі; аңшылық.

\title{
Образ зверя в мировоззрении кочевников: результаты экспедиции на территории Абайского района Восточно-Казахстанской области ${ }^{3}$
}

\section{Умиткалиев Улан Умиткалиулы}

кандидат исторических наук, доцент, заведующий кафедрой археологии и этнологии Евразийского национального университета имени Л.Н. Гумилева.

\begin{abstract}
Аннотация. В этой статье показаны результаты исследования ученых кафедры археологии и этнологии Евразийского национального университета имени Л.Н. Гумилева, осуществленного на базе археологических изысканий, выполненных в комплексном памятнике «Кырык унгир» в поселке Токтамыс Абайского района Восточно-Казахстанской области. Основная цель экспедиции состояла в проведении археологической разведки восточной части низменности Сарыарки, а также в анализе результатов археологических раскопок на памятниках бронзы и раннего железного века, описании объектов, картировании, изучении особенностей петроглифов в регионе. Кроме того, сделаны доказательные выводы по историческому наследию этого региона, в котором сочетаются великие культуры Горного Алтая и Сарыарки.

Заметим, что исследование не ограничивалось археологическими раскопками. Параллельно велись работы по изучению петроглифов в регионе, сбору свежих данных о местных традициях и топонимических данных. В то же время еще один аспект исследования состоял в том, чтобы сосредоточиться на изучении основ народного хозяйства и дифференциации мировоззрение населения. В результате экспедиции был составлен список древних памятников железного века от раннего железного века по региону. Были исследованы 5 объектов раннего железного века. Был обнаружен памятник раннего железного века, а также бронзовые зеркала, каменные бусины и глиняные сосуды, Проведено сравнение находок с результатами изучения сопредельных регионов.

Ключевые слова: Кырык Унгир; Шиликты; Талды I; Талды II; Каракемер; природная среда; наскальные рисунки; изображение кошачьих; охота.
\end{abstract}

\section{ӘОЖ/ УДК 902.01/903.3}

\section{Көшпелілер дүниетанымындағы аң бейнесі: \\ Шығыс Қазақстан облысы, Абай ауданы территориясына жасалған экспедицияның қорытындылары}

\section{Үмітқалиев Ұ.Y.}

Кіріспе. Ерте темір дәуіріндегі аң бейнесі оның пайда болуы мен қалыптасуына қатысты ғылыми зерттеулер кең көлемде қарастырылып, көптеген ғалымдардың қайраткелігімен жарияланды. Негізінен зерттеу ауқымы ерте темір дәуіріне қатысты болғандықтан барлық зерттеушілер тарапынан жасалған пікірлер бір-бірін толықтыра отырып жасалған.

Біздің қарастыратын мәселеміз кешенді зерттеулер болғандықтан қола дәуірінен ерте темір дәуіріне өтуге себеп болған жағдайлардан бастап «аңдық стильдің» қалыптасуына қатысты негізгі себептерге өз пікірлерімізді білдіру.

Соңғы қола дәуіріндегі Қазақстандық тайпалардың мол металл қорларына иелік етуі, соның нәтижесінде металл саудасының өркендеуі Оңтүстік Сібір және Азия жерлерімен байланысты күшейтіп, шаруашылық экономикалық жағынан дамуына қарқын берді. Дамыған тайпалар арасындағы мал үшін, жер

\footnotetext{
${ }^{3}$ Исследование выполнено в рамках проекта «Развитие научно-исследовательской работы по археологии в Восточно-Казахстанской области»
} 
үшін болған соғыстар ерте темір дәуірінде көшпелі жауынгерлік өмір тұрмысына бейімделген қуатты тайпа бірлестіктер одағына алып келді.

Қазақстан жеріндегі дүрбелеңге толы б.д.д. I мыңжылдықтың басы әртүрлі тайпалардың бірігуі, араласуы нәтижесінде тайпалық одақ құрылымының негізі қаланды (Умиткалиев 2014, С.10).

Қола дәуірінің негізгі шаруашылығы шағын егіншілік пен бірге отырықшылыққа негізделген ірі қара малдары мен ұсақ малдардың қолға үйретілуі соған лайықты өнердің де дамуы мен қалыптасуынан тұрды. Қола дәуірі өнерінен хабар беретін қыш ыдыс сыртындағы өрнектер мен тас жәшіктерден табылатын қола және алтын әшекейлердегі геометриялық өрнектер сол кезең шаруашылығымен тығыз байланыстылығын аңғартқандай. Қола дәуіріндегі зергерлік өнердің дамуында ең алғашқы қадамдар тау, өзен, кеңістік, ұлу қабықтары бейнесімен басталып қоғамның келесі сатысына өтерде яғни көшпелі қоғамға дайын күйде келді десе болады.

Қоғамның көшпеліленуімен бірге алыс жақын өлкелерге көше отырып далалы жазықтар мен таулы қыраттардың игерілуі жылқы малының кеңінен қолға үйретіліп мініске қолданылуы, аңшылық кәсіптің дамыған сатысына әкелді. Аңшылықтың дамуы арқылы сақ қоғамындағы тұрғындардың әртүрлі аң құс қасиеттерін жақын танып білуіне жағдай туды. Сол арқылы белгілі бір тотемдік белгілердің туындауы, оларды әспеттеу мен марапаттау қалыптасты деуге болады. Олай деуге себеп көне сақ қоғамындағы аңдық стильдің қалыптасуында белгілі бір тайпалық одақтың өзіндік тотеміне айналған аң немесе құс бейнелерінің пайда болуы. Сол тотемдік аң бейнесі арқылы тайпа мүшелерінің өзіндік есімдерінің өзі соған қатысты болуы ғажап емес. Мәселен, таутеке образы тотемге айналған тайпалық бірлестікте көсемнің аты таутекенің мүйізі, немесе басы деп аталса қалған мүшелері тайпа құрамына таратылып берілуі мүмкін.

Сақ заманының бас кезіне тән «көсемдік» идеясы, яғни, тірі басшыларды дәріптеу рәсімі олардың «жанын жөнелту» үшін көк пен жерді дәнекерлеуші ерекше құрылымдар тұрғызу қажеттігі туындады. Осы ескерткіштердің шығу тегі жайлы және олардың шығыс идеясын аңғартатын жер асты дәлізі (дромос) немесе «мұртты» обалардың қола дәуірі құрылымдарымен байланыстылығын атап өтуге болады. Жекелеп алғанда Орталық Қазақстанның кейінгі қола дәуірінің беғазы-дәндібай мәдениетінің шығысқа бағытталған ұзын дәлізді элиталық ескерткіштерімен (мавзолейлерімен) байланыстылығы туралы пікір айтылған (Бейсенов 1997, С.10).

Сақ қоғамындағы шаруашылық, мәдени, дүниетанымдық және әлеуметтік көріністерден хабар беретін ірі ақсүйек обалары бүгінгі күні терең талдау мен зерттеуді қажет етеді. Әсіресе ірі обалардың орналасу жағдайы, құрылыс материалдары, көне құрылыстың салыну жолдары, көлемі мен архитектурасына байланысты шешімдер болып отыр.

Мақала авторының ат салысуымен 2003 жылдан бастап Ә.Т. Төлеубаевтың жетекшілігімен Шығыс Қазақстан өңірінде он жылдан астам зерттеу жұмыстары жүргізілді. Осы зерттеулер барысында әсіресе сақ дәуірінің ірі обаларының әлеуметтік дәрежесін анықтауға қатысты тұжырымдарды Шілікті кешенді ескерткіштері көрсетті. Соның ішінде атап көрсететін бір жай, Бәйге-төбе обасындағы қазба барысында топырақ жабындысы астындағы тас құрылыстан толық таутеке сүйегінің табылуын айта кету керек (Төлеубаев 2013, Б.121).

Сонымен бірге осы обадан табылған археологиялық артефрактілер ішінде ең көп кездескен аң бейнесіндегі таутеке образы осы жерленуші көсемнің жалпы тайпалық одақтың тотемі таутеке болды ма? - деген ойларға жетелейді. 


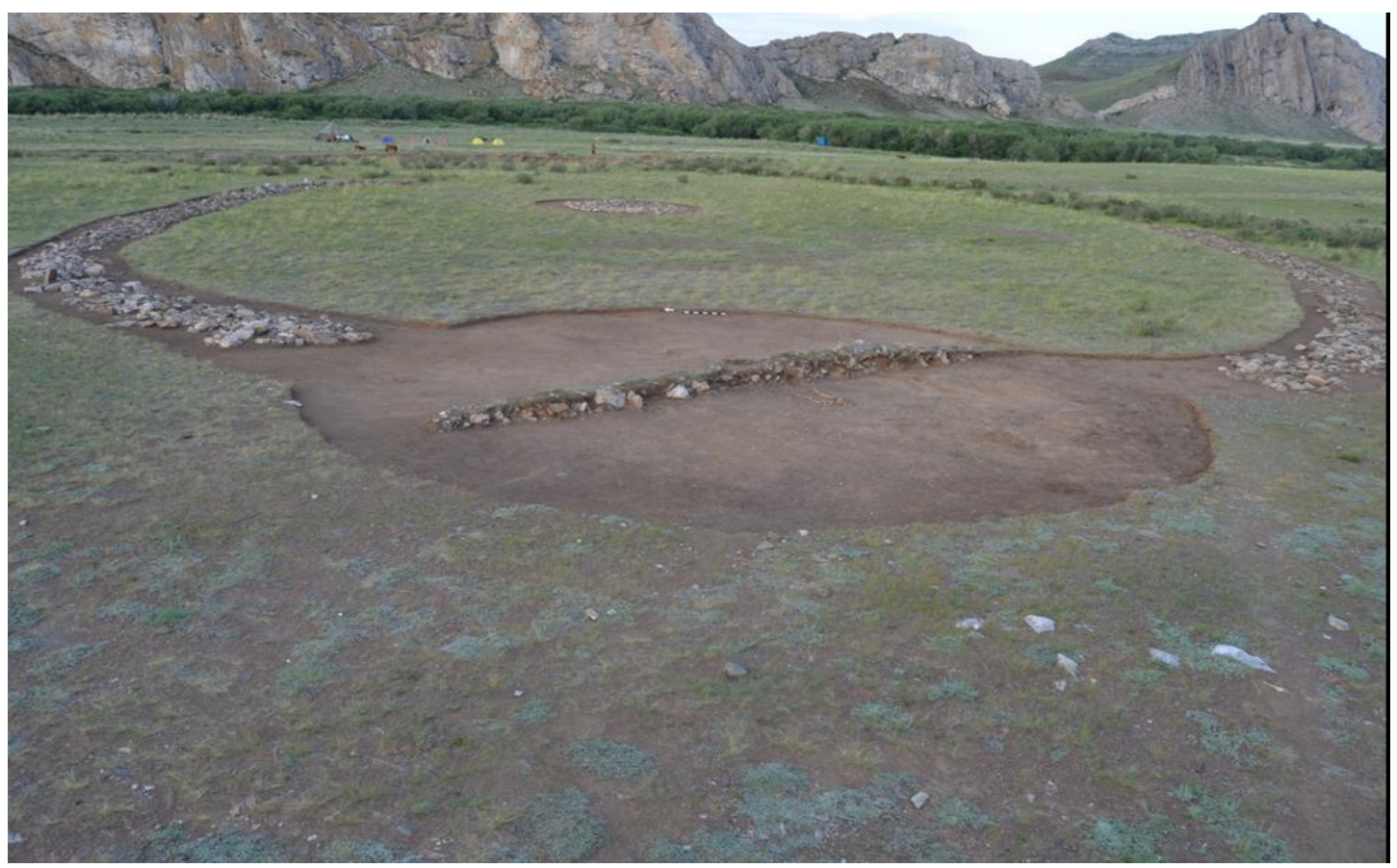

1 cурет. Мұртты оба. Солтүстік шығыстан қарағандағы қазбадан кейінгі жалпы көрінісі

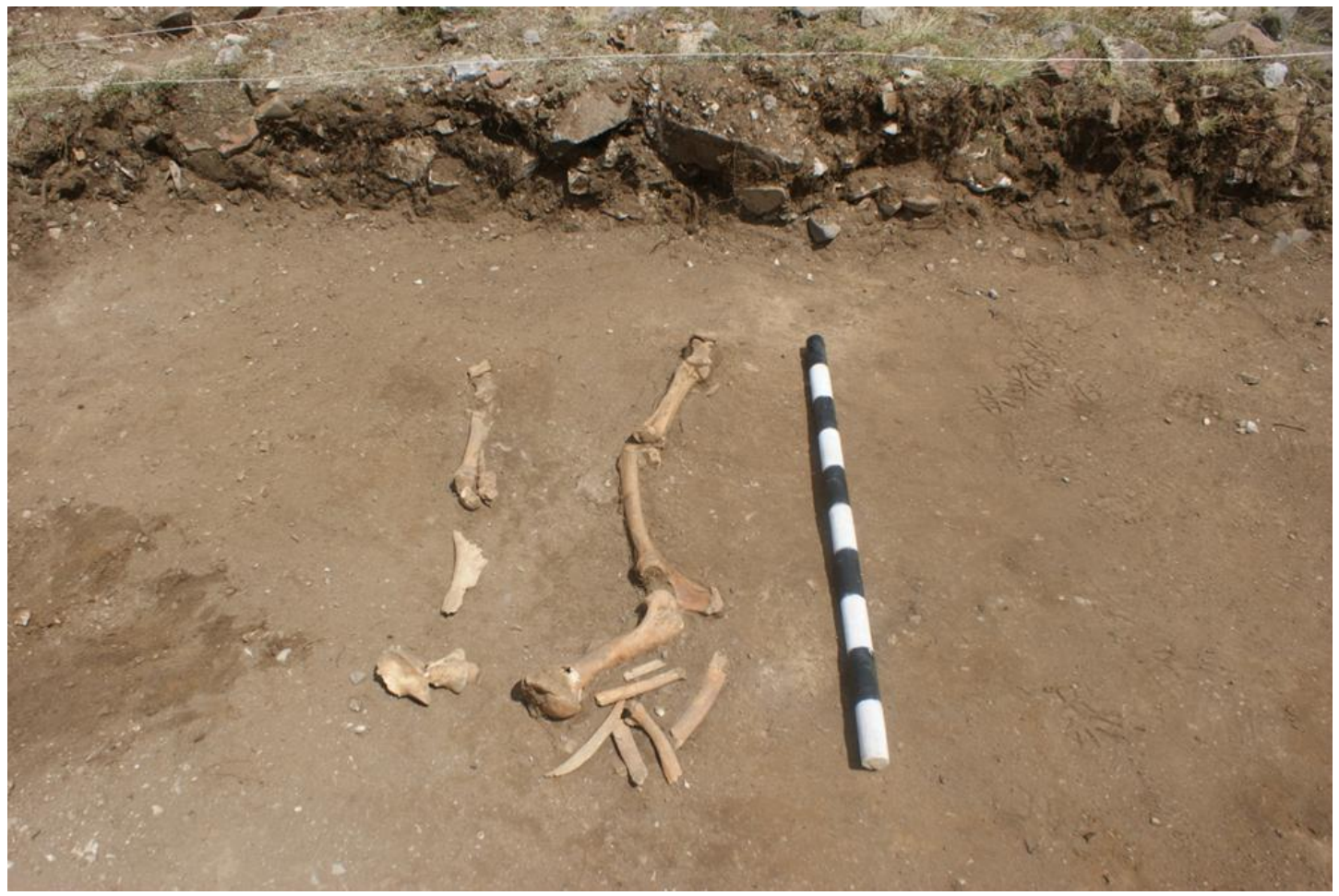

2 сурет. Мұртты оба. Жылқы сүйектері. Батыстан қарағандағы көрініс 


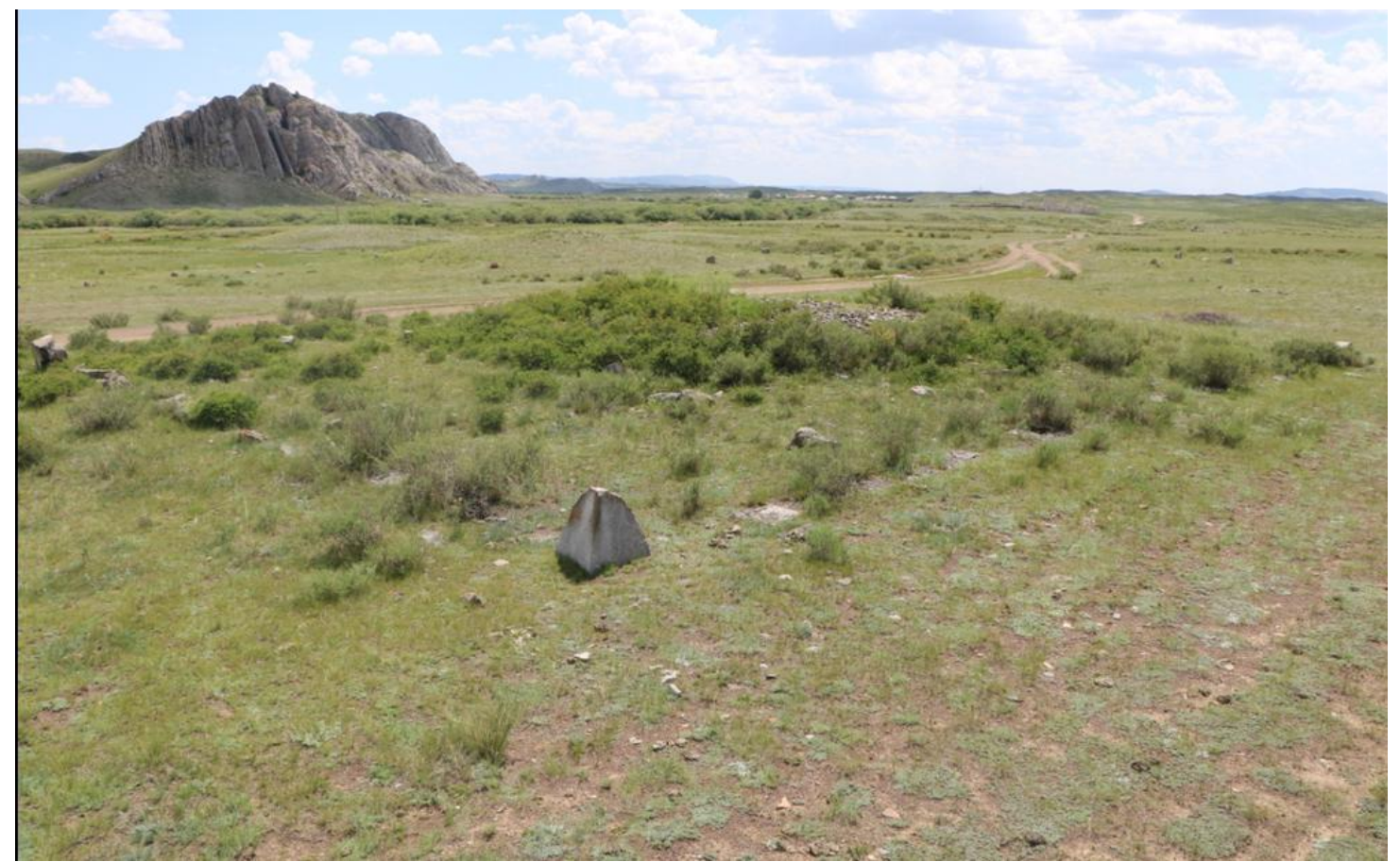

3 сурет. № 25 қорған. Солтүстік батыстан қарағандағы қазбаға дейінгі көрінісі

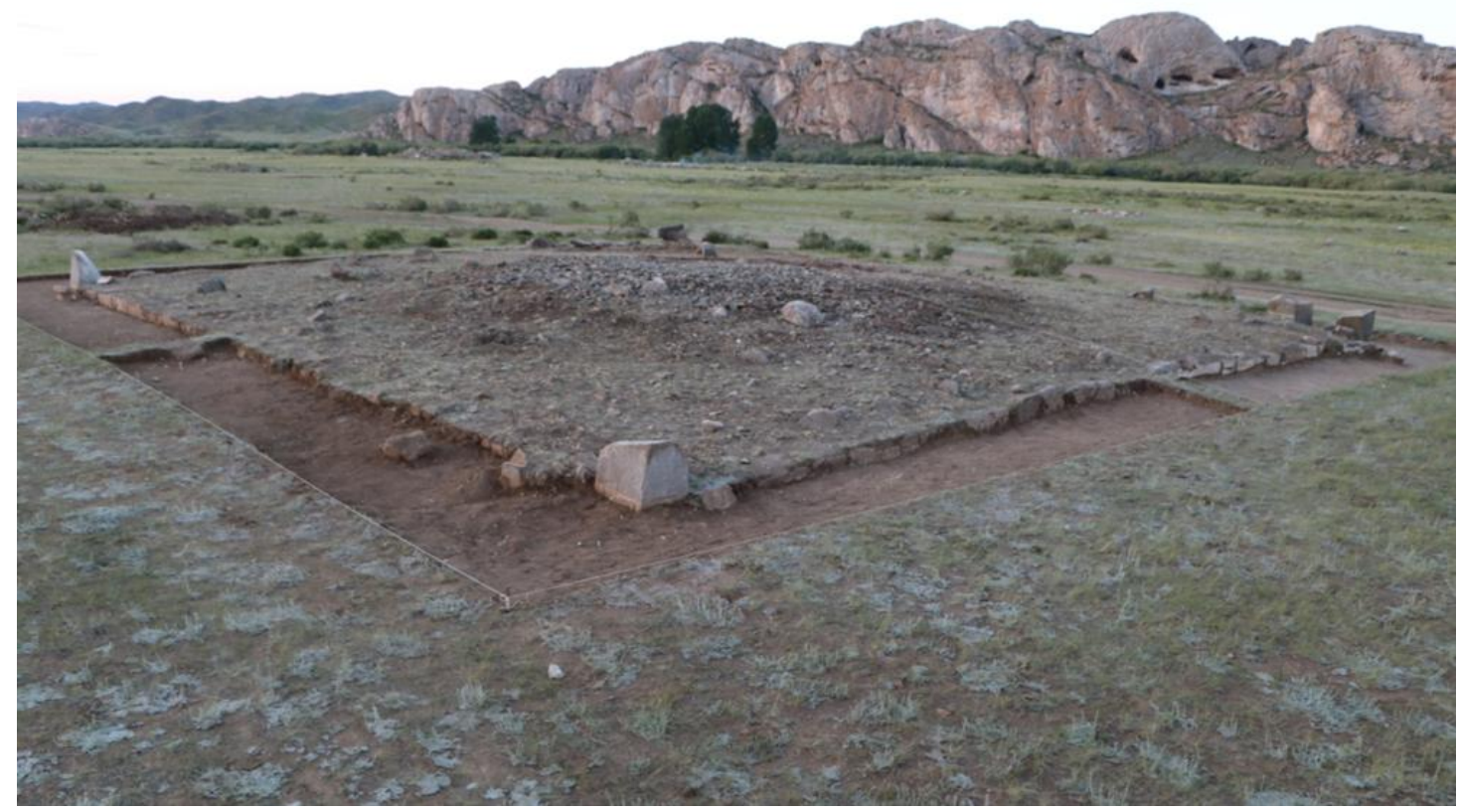

4 cypem. № 25 қорған. Оңтүстік батыстан қарағандағы қазба барысынан көрінісі 
Сақ обаларындағы алтын әшекей бұйымдардың аса күрделі аң стильіндегі зергерлік өнері мен сынамаларына қарап отырып бірнеше күнде ғана дайындалмағанын көреміз. Ол үшін арнайы зергерлерге өздерінің тайпалық ерекшелігін көрсететін аңдық стильде әшекейлер жасауға тапсырыс беріп дайындатқызған деп топшылауға да болады. Кейде қазақ халқында кездесетін жасы жеткен үлкен апа, әжелердің өздеріне ақыреттік маталарын дайындап қоюына қарап, сақ көсемдері де алтынмен апталған салттық киімдерін алдын-ала арнайы жасатып сандыққа салып қойған ба деп те жорамалдауға болады.

Бұл тұжырымдарға қарап, сақ қоғамында тек тайпа көсемдеріне ғана ақыреттік киімдер әзірленіп, сонымен жерленді деген ұшқары пікір тудырудан аулақпыз. Өйткені Еуразияның кең жазиралы өлкелерінде мекендеген көшпелі тайпалардың өзіндік дүниетанымы қалыптасып үлгеруімен бірге, мол металл қорларына иелік етуінің өзі қарапайым тайпа мүшелерінің де алтынмен апталып киіндіріліп, мәңгілік мекеніне аттанғанын көреміз. Сонымен бірге тайпа мүшелерінің ақіреттік киімін әзірлетуде жоғарыда айтып кеткен заңдылықты сақтай отырып, өз тотемдеріне айналған аң бейнелері басымдыққа ие болған.

2014 жылдан бастап Л.Н. Гумилев атындағы Еуразия ұлттық университетінің ректоры Сыдықов Ерлан Батташұлының бастамасымен бірнеше жыл-дың көлемінде «Қазақстан археологиялық экспедициясы» құрылып, соның негізінде тарих фракультетінің археологтары Ақмола облысының территориясында Атбасар өңірінде, Көкшетау өңірінде, Шағалалы өзенінің аңғарында табысты зерттеулер жүргізген болатын. Осы экспедиция негізінде 2016 жылы Шығыс Қазақстан облысының Абай ауданында, Тоқтамыс елдімекеніне қарасты Қыры-қүңгір қорымында археологиялық зерттеулер жүргізген болатын.

Қорымда жүзден аса қола және ерте темір дәуірлерінің ескерткіштері орналасқан. Солардың ішінде біздің зерттеулерімізбен үш ерте темір дәуірінің ескерткішіне қазба жұмысы жүргізілді. Оның біреуі «мұртты оба», қалған екеуі кіші көлемдегі тас үйінділі бір тізбекте орналасқан обалар. Жалпы қорымның солтүстік шығыс шетіне қарай орналасқан, Шаған өзенінің үшінші террасасында Шаған өзенінен 230 метр жерде жалғыз «мұртты оба» орналасқан. Кешенді құрылыс негізгі обадан көлемі ШБ - 12м, ОС - 11м, биіктігі 0,5 м. Оба үйіндісі әр түрлі көлемдегі тас аралас топырақпен үйілген. Негізгі обадан үш метрден кейін екі тас тізбекті мұртшалар тізбегі шығысқа қарай салынған. Солтүстік тас тізбектің ұзындығы 47,5 метр, ені орта есеппен 3 метр. Оңтүстік тас тізбектің ұзындығы 41,7метр, ені орта есеппен 2,5 метр.

Екі жақ тас тізбектің де биіктігі онша биік емес 10-15 см.

Негізгі обаға жүргізілген қазба жұмыстары нәтижесінде тас үйінді құрылысынан айрықша құрылыс немесе жерлеу қабірі анықталмады. Тек обаның оңтүстік батыс бөлігінен толық сақталған жылқының алдыңғы екі аяқ жіліктері табылса, солтүстік шығыс бөліктен шашылған жылқы сүйектерінің жекелеген бөлшектері (қабырға, омыртқа, жілік және бас сүйектің жекелеген бөлшектері) табылды. Сонымен бірге, осы солтүстік шығыс бөліктен бірнеше жерден өртенген от орындары мен күл қалдықтары табылды. Екі мұртшаны тазалау кезінде де тас тізбектің әр жерінен от орындары мен күл қалдықтары табылған болатын. Жылқы сүйектерін 2015 жылы А.З.Бейсеновтың зерттеу қорытындылары негізінде арнайы зертханаға сынама алуға беру барысында б.д.д 5 ғасырмен мерзімделетінін дәлелдеп беріп отыр.

Біздің зерттеулеріміз бойынша Қырықүңгір қорымында жүргізілген келесі бір ерте темір дәуіріне жатқызылатын ескерткіш №37 оба. Қорымда орналасқан мұртты обадан оңтүстік-шығысқа қарай 68 метр жерде орналасқан. Оба дөңгелек формада әртүрлі көлемдегі аралас өзеннің малта тастарымен,таудың 
жақпар тастарымен үйілген. Обаның диаметрі 6 метр, биіктігі 0,2 метр. Обаның орталық бөлігінен тас үйіндісін алғаннан кейін оңтүстік-шығыс, солтүстік-батыс бағытына бағытталған қабір анықталды. Қабірдің ұзын бойы 2 метр, ені 1,35 см, тереңдігі 1,75 см. Қабір ішін тазалау кезінде 60 см тереңдіктен бастап әр түрлі көлемдегі тас шыға бастады. Қабір іші тереңдігі 1,60 см-ге жеткенде көлденеңінен жатқызылған плита тастар кездесті. Тастардың көлемі 60×30×10 смден 110x40x20 см-ге дейін болады. Тас плиталар сынған күйінде шашылып кездесті. Тастардан тазаланған қабір ішінен 1,70 см тереңдіктен анатомиялық күйін сақтаған адам сүйегі табылды. Адамның басы солтүтік-батысқа қаратылып шалқасынан жерленген. Адамның бас жағынан солтүстік-батыс бетінен 1,75 см тереңдіктен бүтін қызыл түсті кішкене қыш ыдыс табылды. Қыш ыдыс сыртында ешқандай өрнек салынбаған биіктігі $11 \mathrm{~cm}$, ернеуінің диаметрі 7,5 cм (Pedracki Michal, Айтбаев 2016, C.220-225).

Қырықүңгір қорымында зерттелген келесі бір ерте темір дәуірінің ескерткіші №38 обасы.

Ескерткіш №37 обаның солтүстік - шығысында жапсарласа орналасқан. Оба тас аралас топырақпен сәл сопақтау болып үйілген. Диаметрі шығысбатыс бағытында 5 метр, оңтүстік-солтүстік бағытында 4 метр. Тас үйіндісін тазалау барысында тігінен сәл ішке қарай жантайта салынған тас қоршау анықталды. Тас қоршаудың көлемі солтүстік - оңтүстік бағытында 3,7 м, батыс - шығыс бағытында 4,9 м.

Тас қоршаудың ортасынан солтүстік-батыс, оңтүстік-шығыс бағытында қабір шұңқыры анықталды. Қабірдің ұзындығы 2 метр 20 см, ені 1 метр 90 см. Қабір тереңдігі 1 метр 95 см.

Қабір іші әртүрлі көлемдегі таспен толтырылған. Қабір ішінің тереңдігі 1,80 см-ге жеткенде көлденең жабылған жалпақ тастар кездесе бастады. Бірақ барлық тастар сындырылып тасталғаны байқалады. Осы жалпақ тастар астынан 1,90 см тереңдіктен анатомиялық күйін сақтаған адам сүйегі табылды. Адам сүйегінің бас жағынан нақты айтқанда мойын тұсынан әр жерде шашылған жасыл түсті және ақ түсті моншақтар табылды. Жерленушінің сол жақ құлағының тұсынан жалғыз алтын сырға және кеуде тұсынан сүйек астынан аң бейнесіндегі алтын қапсырма табылды. Сонымен бірге адамның сол қолының басынан жасыл түске енген дөңгелек қола айна табылды. Қола айнаның ешқандай өрнегі жоқ, тек артында кішкене ұстайтын ілмегі қоса құйылып жасалған. Қабір ішінде адам сүйегімен бірге басқа ешқандай заттар табылған жоқ. Соған қарағанда және қабір құрылысындағы тастардың шашы-лып кездесуіне қарап оба қатты тоналған. Алайда үш жылда зерттелген ерте темір дәуіріне жататын үш обаның табылымдарымен нақты мерзімдемелік уақытын анықтауға мүмкіндіктер бар деп айта аламыз.

Қазба барысында табылған Қырықүңгір қорымындағы археологиялық жәдігерлердің ішіндегі ең біздің мақаламызға арқау болғалы отырған №38 обадан табылған аң стильіндегі мысық тұқымдас аңның бейнесіндегі алтын қапсырма. Қазбадан табылған аң бейнесіндегі қапсырма жалғыз болғанмен осы бейнені қайталайтын образдар Орталық Қазақстанда А.З. Бейсенов қазбаларында Талды-2, Ашутасты, Ақбейіт ескерткіштерінде кездесетіндігі айтылады (Бейсенов, Джумабекова, Базарбаева 2015, Б.83).

Сонымен бірге осындай мысық тұқымдас жыртқыштың Еуразия даласында кең тарағандығын және оның Аржан-2 ескерткішінде, Түгіскен ескерткіштерінде, Обские Плесы-2, Кошпей -1 де кездесуі айтылады (Богданов 2006, С.27).

Талды-2 ескерткішінде кездесетін мысық тұқымдас жыртқыштың ұқсас үлгісі Түгіскен қорымындағы М.И. Артомонов зерттеулеріндегі жыртқышпен ұқсас 


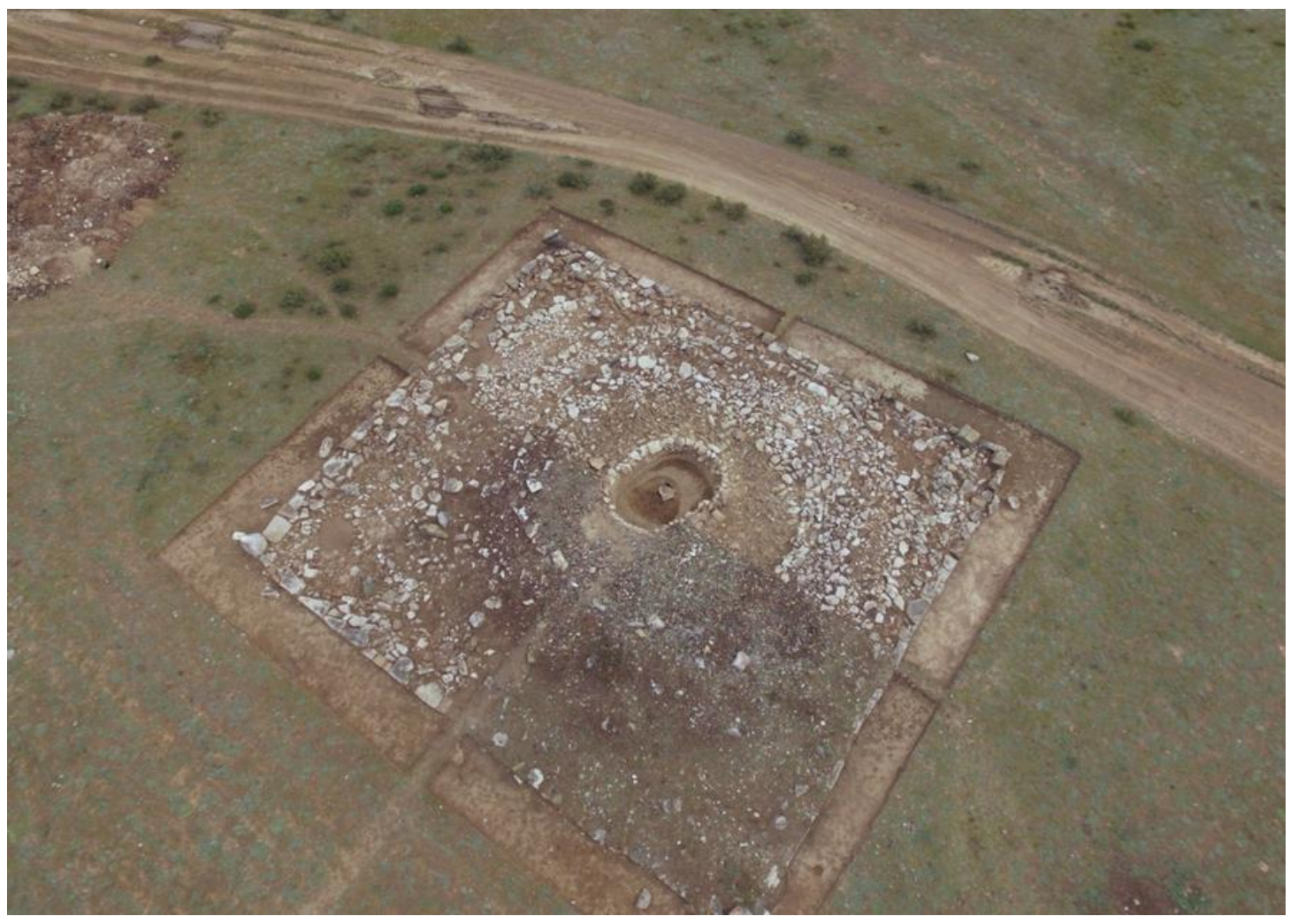

5 cypem. № 25 қорған. Қазбадан кейінгі жалпы көрінісі

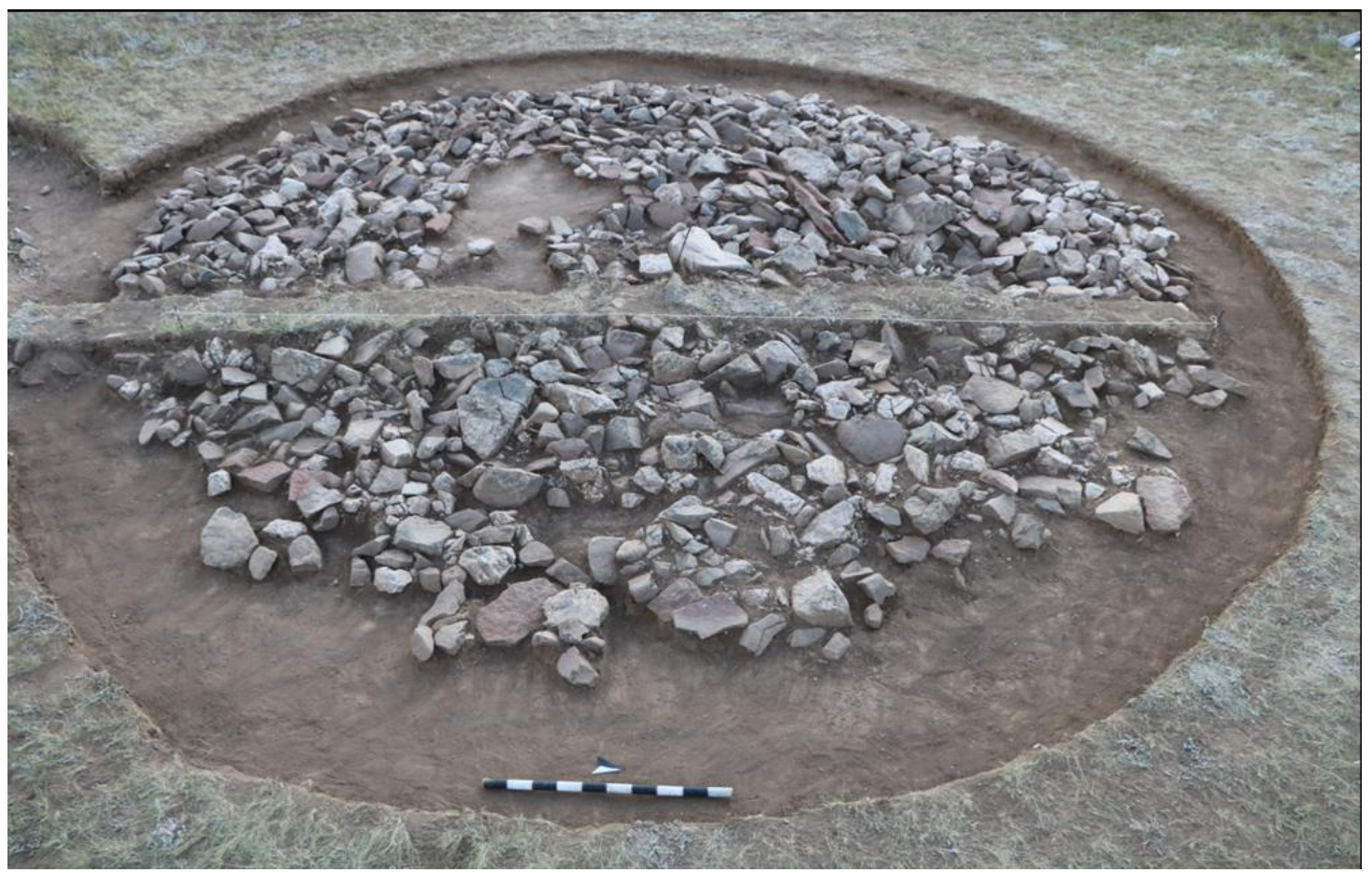

7 cypem. № 38 қорған. Шым қабаты алынғаннан кейінгі шығыстан қарағандағы көрінісі 


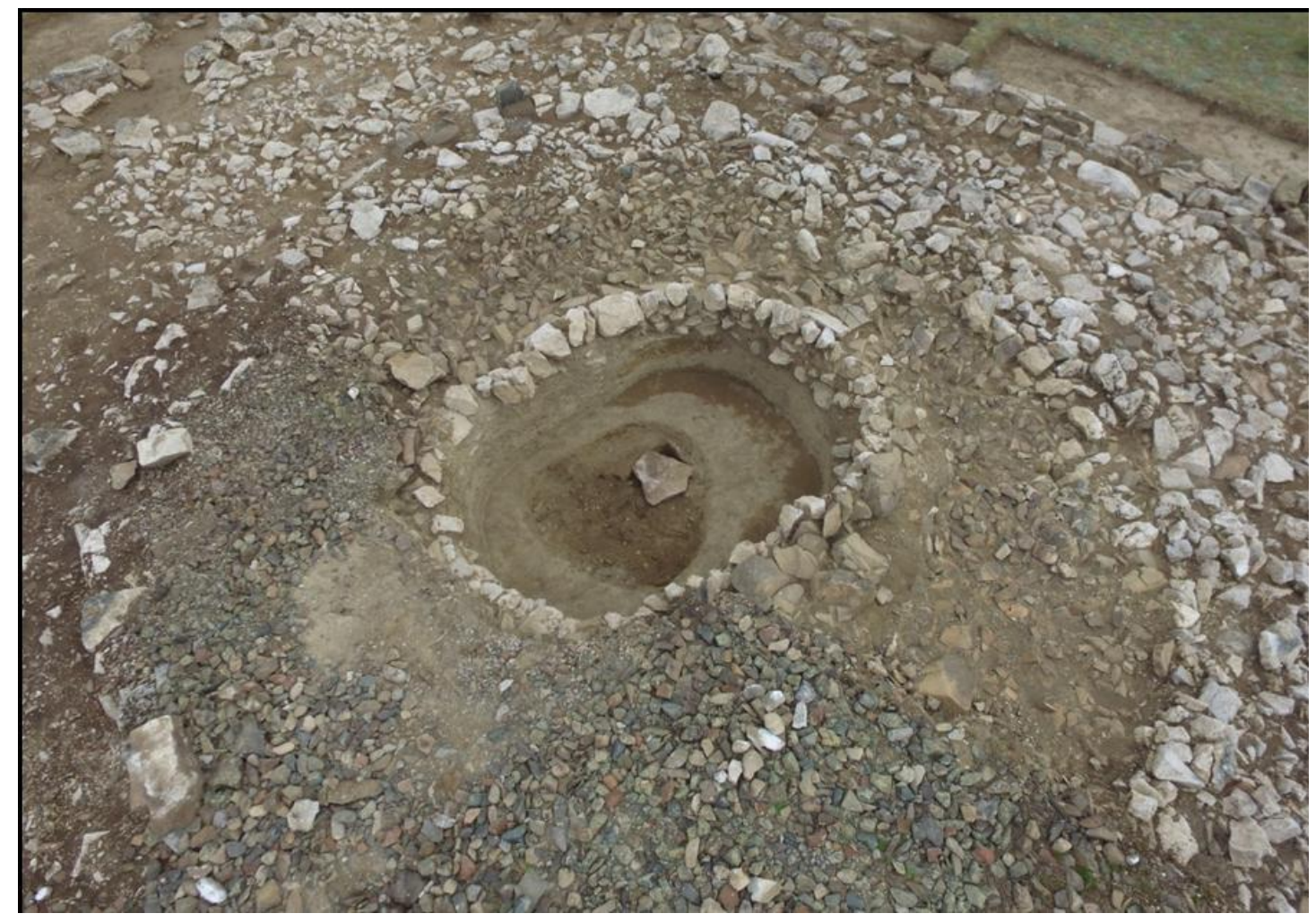

6 cypem. № 25 қорған.Қабіршұңқырының жалпы көрінісі

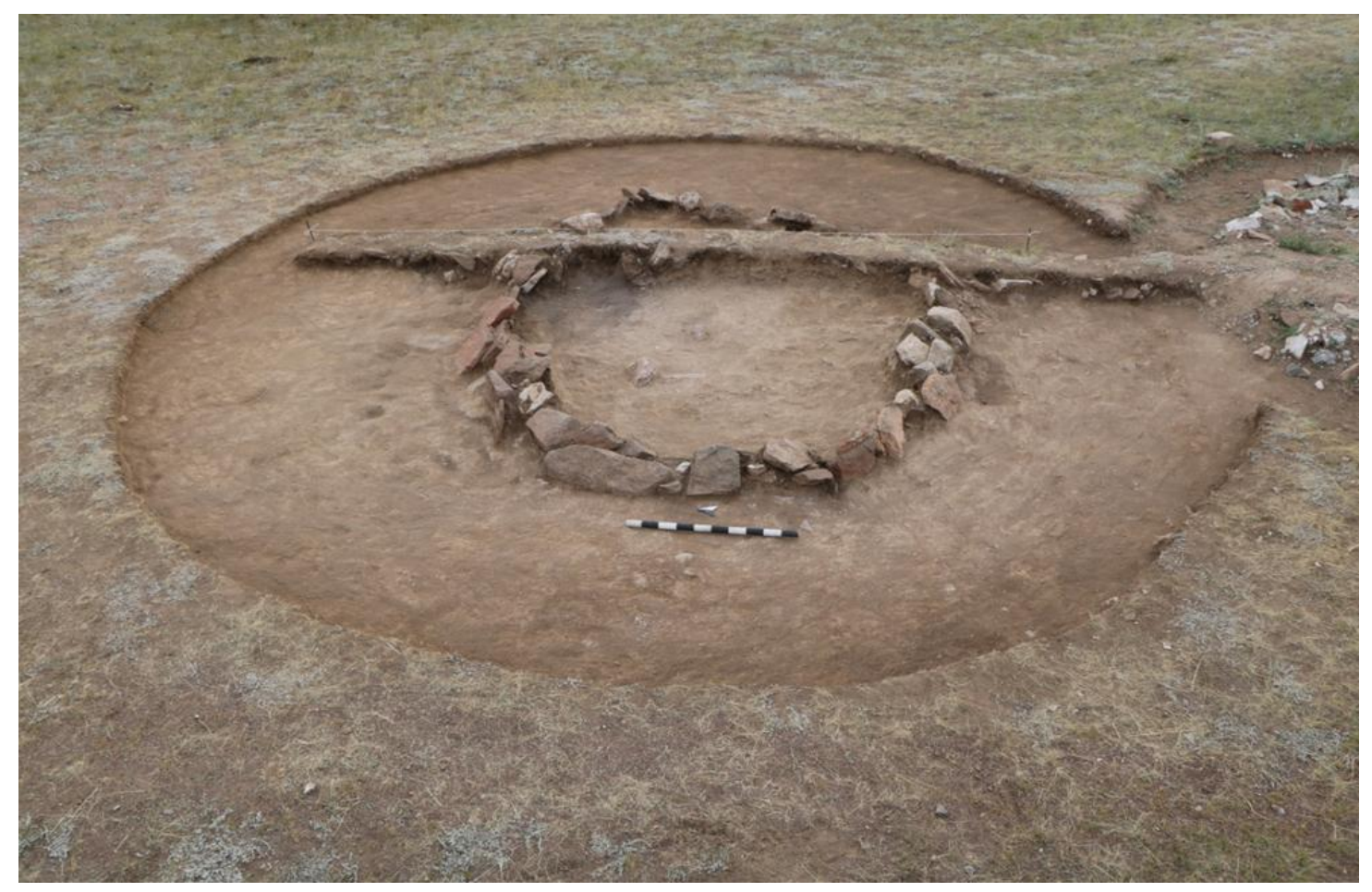

8 cypem. № 38 қорған. Қорған ішіндегі қоршау. Батыстан қарағандағы көрініс 


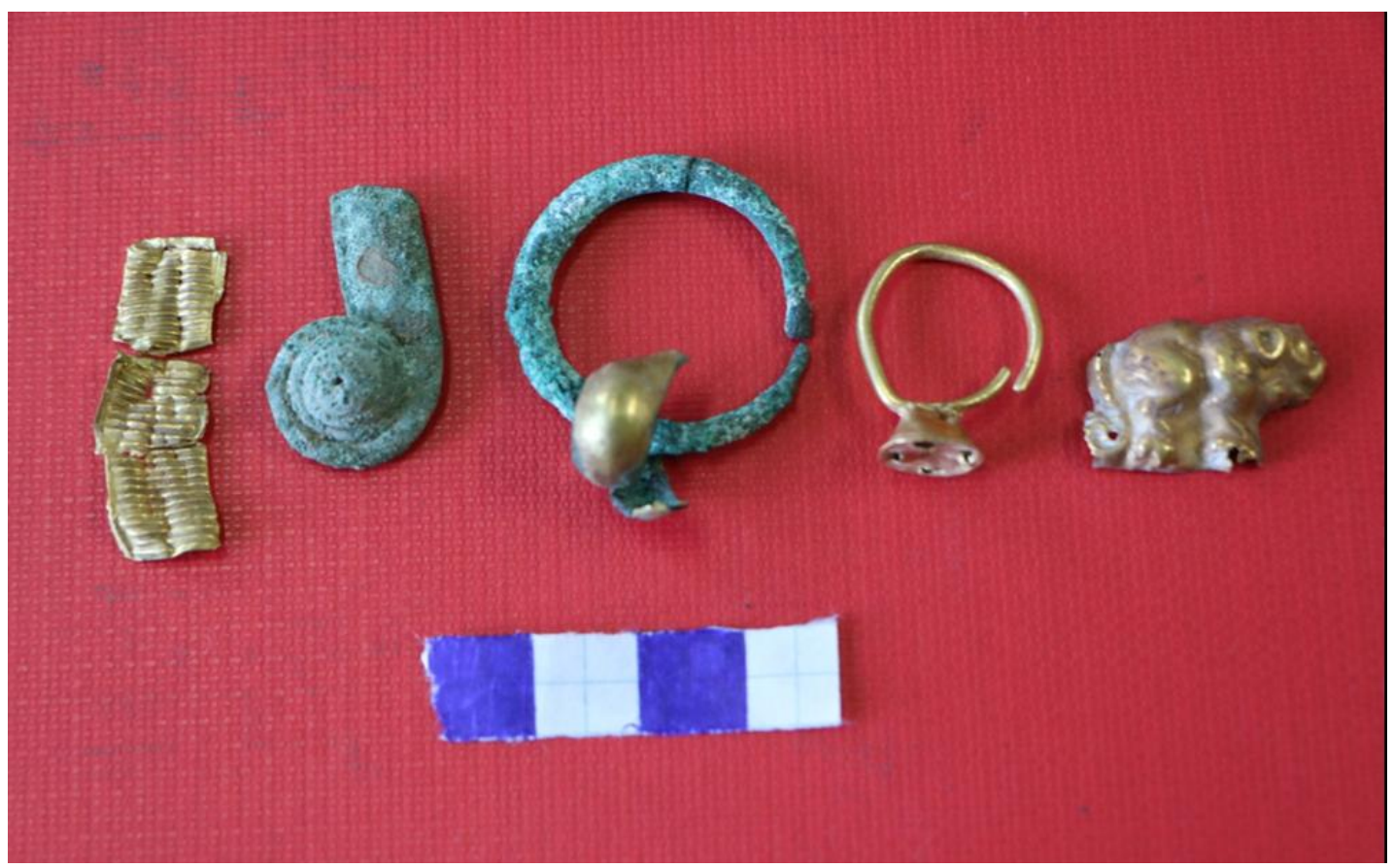

9 cypem. №25 және №38 қорғандардан табылған әшекей бұйымдар

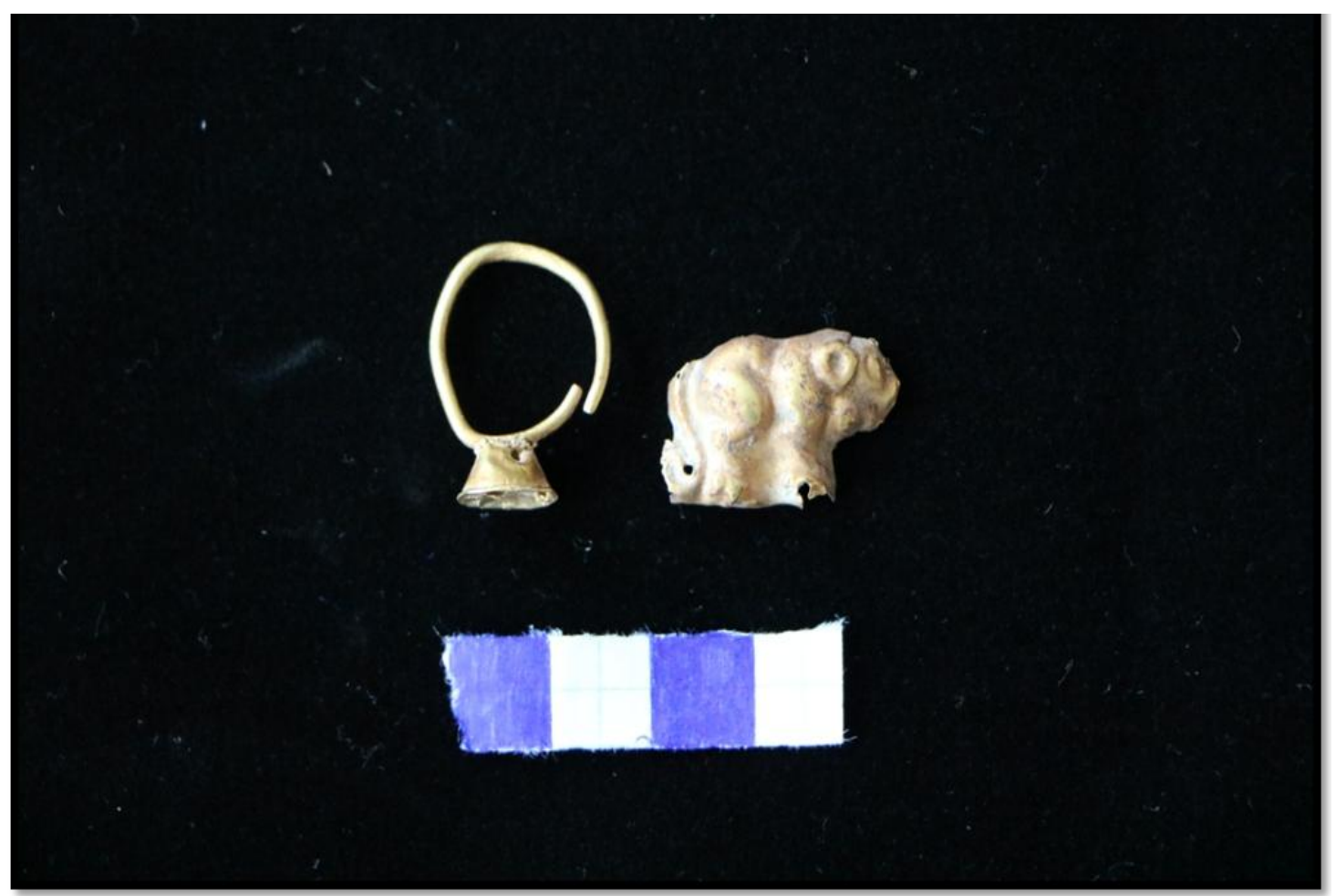

11 сурет. №38 қорған. Алтын сырға және аң стилінде жасалған қапсырма 


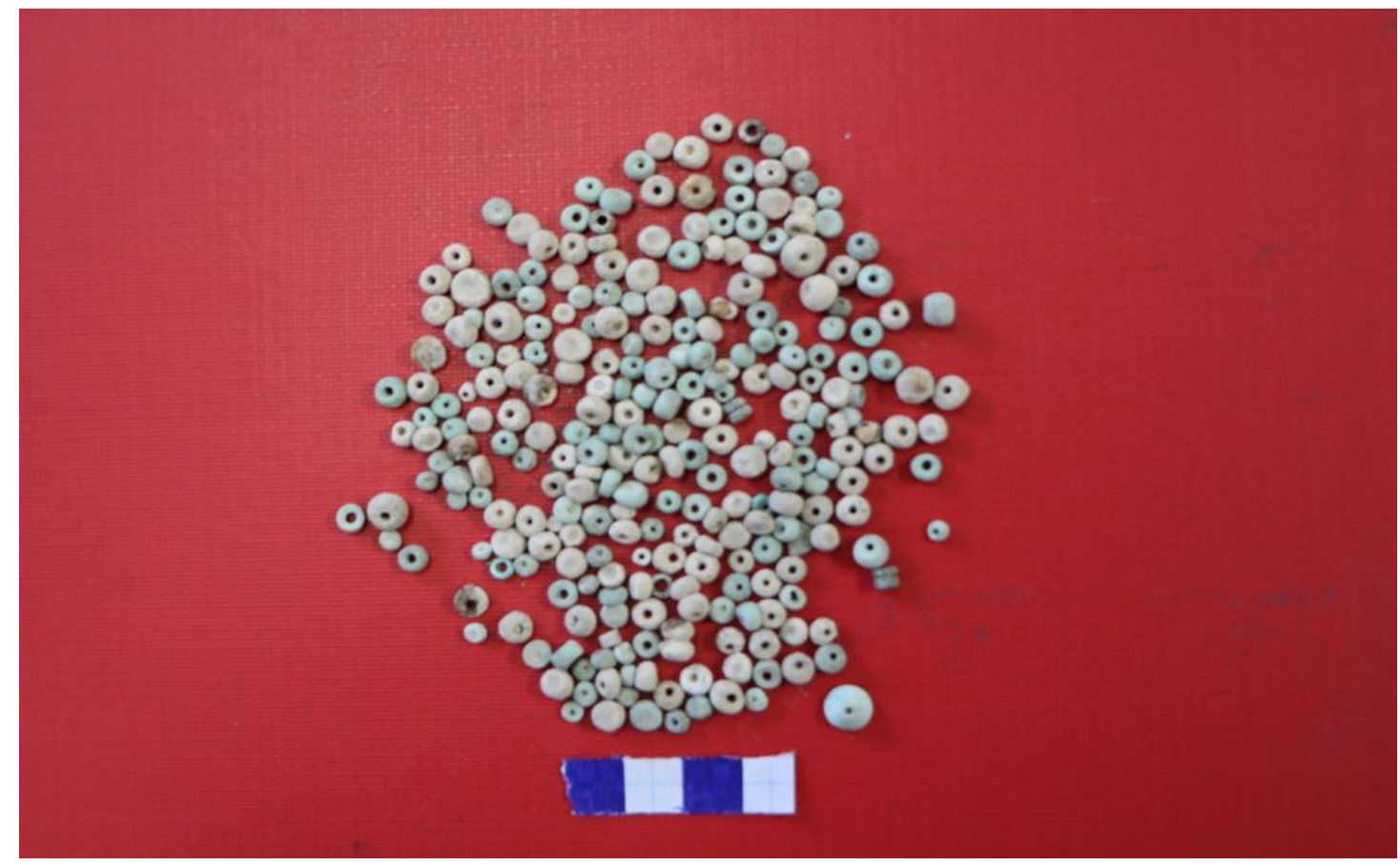

10 cypem. №38 қорған. Сүйектен және көгілдір тастан жасалған моншақ фрагменттері

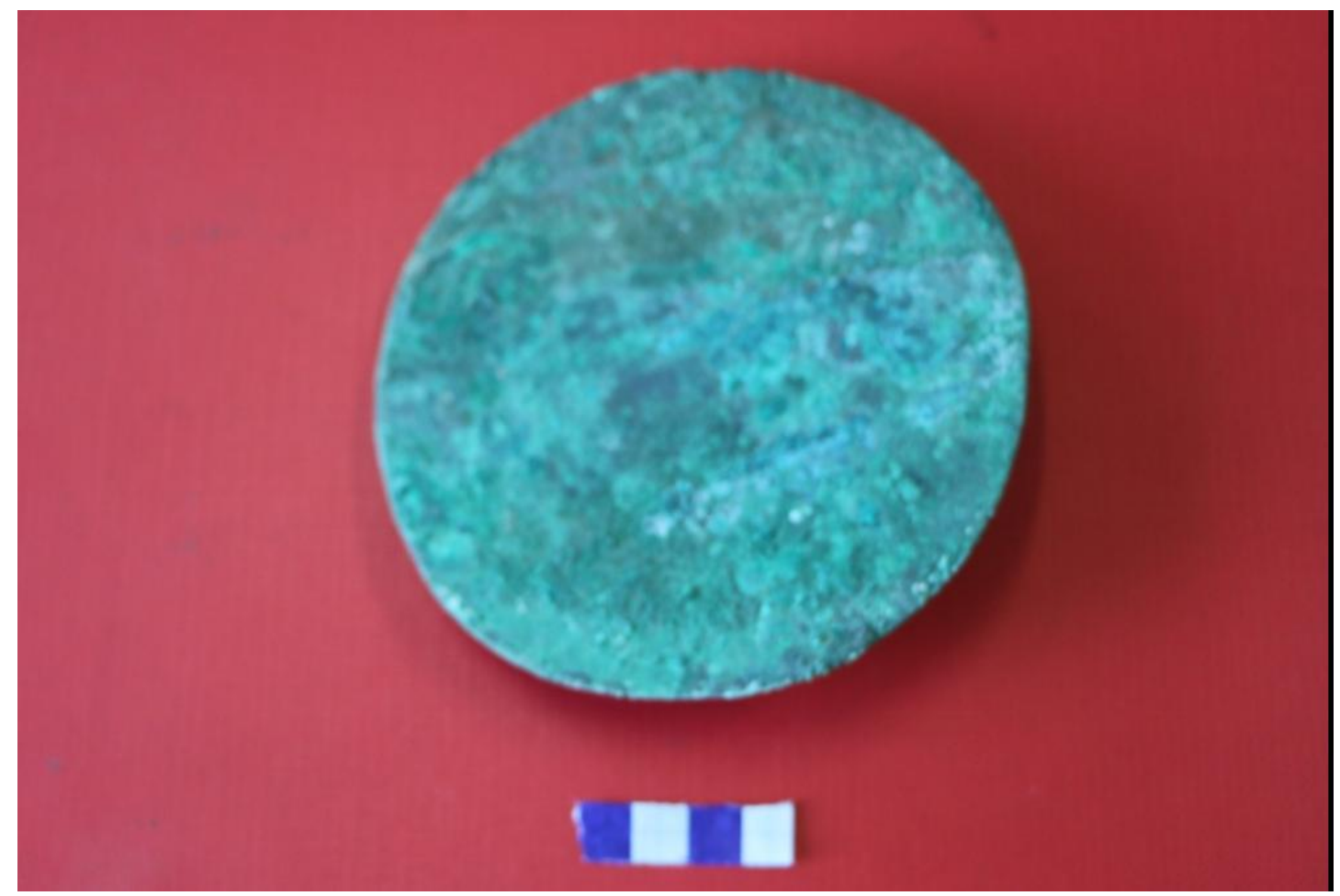

12 сурет. №38 қорған. Қоладан жасалған айна 
екендігі айтылады. Алайда М.И. Артомонов бұл жыртқышты жүріп бара жатқан немесе жатқан арыстан бейнесіне жатқызады (Артомонов 1973, С.21-22).

Ал Талды-2 ескерткішінде кездесетін жыртқыштар арыстан бейнесінде емес екені анық, өйткені арыстан кейпіндегі образ сақ өнерінде осы уақытқа дейін еш жерде кездеспеген болатын. Сонымен бірге аң бейнелерінің қалыптасуы мен оның бейнеленуі жергілікті фрауна мен фрлораға негізделгендіктен Орталық Қазақстан территориясында арыстанның мекендеуіне табиғи жағдайдың келмеуін де ескеру керек. Оған көптеген мысалдар мен дәйектерді келтіруге болады. (Қыстың қатты болуы, жергілікті жерде оған қажетті аулайтын аңның болмауы т.б себептер).

Ал біздің зерттеулеріміздегі табылған мысық тұқымдас жануардың бейнесіне қарап, оның құйрығының ұзындығына қарап барыс деуге әбден болады. Ал оның жасалу технологиясы мен композициясы және сюжеттік ерекшелігі көне шебердің дизайнерлік қабілеті өте жоғары деңгейде болғандығын аңғару қиын емес. Өйткені жоғарыда келтірген зерттеушілер пікірі бойынша осы қапсырмаларды жасаушылар ол аңнан хабары болмай, штамптап көшіре берген деген пікір айтылған болатын. Алайда бұл мысық тұқымдас жануардың бейнесі жұқа алтын қаңылтырға салынғандықтан оның бұлшық еттері мен негізгі серпімділікті көрсететін дене мүшелері айқын берілген. Сол себепті де қапсырмада әлдеқайда ірі жануардың бейнесіне ұқсап көрінеді. Оның негізгі контурлары бойынша бажайлап қарар болсақ, қар барысы екендігін анық аңғарамыз. Ал жергілікті фаунада мекендеген аңды бейнелеуде жоғарыда айтып кеткендей, тайпалық бірлестіктің негізгі тотемі болуының өзі ол бейне жөнінде көне тұрғындардың танымы ұшқары болды деп айта алмаймыз.

Мысық бейнесіндегі жыртқыштың барыс деуге негіз болатын тағы бір себеп оның аулайтын жемі таутеке мен арқардың осы жергілікті фаунада мекендеуі негіз бола алады.

Енді осы мысық тұқымдас жануардың мерзімдік даму ерекшелігіне қарай Еуразия даласында кездесетін үлгілеріне қарай Чугунов К.В жақсы сипаттап кеткен. Оның пікірінше, Аржан-2, Шілікті, Талды-2 және тағы басқа ескерткіштерде кездесетін барлық аңдар бейнесінің көркемдік ерекшелігіне қарай оның синкретикалық образға ауысуы сияқты мәселелерді қозғай келе осы құйрығын шиырған мысық тұқымдас аң бейнесі б.д.д 6 ғасырдың соңы мен 5 ғасырларға сәйкес келетіні айтылады (Чугунов 2015, С.402).

Яғни, өткен 2014 жылғы қазба маусымында табылған мұртты оба табылымындағы жылқы сүйектеріне жасалған сынама әдісінің қорытындысы бойынша және мысық тұқымдас жануардың б.д.д 5-4 ғасырларда кең тарағанына қарай, қола айнаның аналогиясына қарай отырып Қырықүңгір ескерткішінде зерттелген ерте темір дәуірінің үш ескерткішінің де б.д.д 5 ғасырмен мерзімделетін ескерткіш деуге толық негіз болып отыр.

Қорыта келгенде, қазіргі таңдағы Қазақстан археологиясының негізгі міндеттерінің бірі ғылыми тұжырым жасау үшін кешенді түрде жасалған зерттеулер нәтижесінде қорытындыға келу. Соның қатарында этно-археологиялық сабақтастық тұрғысында зерттеулердің маңызы зор екендігін айта кету керек. Осы мақалаға арқау болып отырған аң бейнесіне қатысты тұжырымдарды жасауда көптеген зерттеушілер аң бейнесінің қайнары үнді-иран тамырынан бастау алады деген кереғар пікірлер қалыптасқан. Бұл жерде басты орында жергілікті табиғи орта, соған байланысты қалыптасатын аңдық бейнелердің берілуі, олардың ешқайдан алынбай өздері көрген бейнелерді бейнелейтінін 
ерекше ескерген жөн. Ал аң бейнесінің негізгі үлкен дүниетанымдық биікке көтерілу кезеңі - ерте темір дәуірлерінің басы мен орта ширегіне тұспа-тұс келеді. Ал аңдық бейнелердің жоғалып орнына полихромды стильдің басуына себеп болған нәрсе қоғамда мал шаруашылығының бірінші орынға шығуымен бірге оның негізгі тотемдік белгіге айналдырумен түсіндіруге болады. Ал оны тереңдете сипаттау келесі зертттелердің бағыты болмақ.

\section{Әдебиеттер тізімі/ Список литературы}

1. Умиткалиев У.У. Архитетура и семантика курганов раннего железного века. // Методология, методика и практика инноваций. Интеграция российского и зарубежного опыта в экономике, проектном менеджменте образовании, юриспруденции, языкознании, культурологии и др 29-30 декабря 2014 года. г. Санкт-Петербург. - СПб: Изд-во «КултьИнформПресс», 2014. - С.135-139. 2. Бейсенов А.3. Погребальные памятники и культово-ритуальные сооружения древних номадов Центрального Казахстана (7-1 вв. до н.э.): автореф. Дис. . канд. Ист. Наук. - Алматы, 1997

3. Толеубаев Ә. Золотые курганы Шиликты.// Қазақстан археологиясының қола және ерте темір дәуірі мәселелері. - Алматы: Service Press, 2013. - 121 б.

4. Pedracki Michal, Айтбаев А.Б. 2015 г. Восточно-Казахстанская область. Археологические раскопки в могильнике Кырыкунгир. // Алтай - түркі әлемінің алтын бесігі - Өскемен, 2016 - 294 б.

5. Бейсенов А.3, Джумабекова Г.С, Базарбаева Г.А. Искусство саков Сарыарки. - Алматы: Институт археологии им. А.Х. Маргулана; «Бегазы-Тасмола» , 2015. - 168 с. И цв.ил.

6. Богданов Е.С. Образ хищника в пластическом искусстве кочевых народов Центральной Азии (скифо-сибирская художественная традиция). - Новосибирск: ИАЭТ СО РАН, 2006.

7. Артомонов М.И. Сокровище саков. - М.: «Искусство», 1973.

8. Чугунов К.В. Искусство раннесакского времени тывы и Казахстана:опыт сравнительного анализа и хронология.// Сакская культура Сарыарки в контексте изучения этносоциокультурных процессов Степной Евразии. - Алматы: НИЦИА «Бегазы-Тасмола», 2015. - 446 с.

\section{Reference}

Artomonov 1973 - Artomonov, MI 1973, Sokrovishhe sakov, «Iskusstvo», Moscow. (Artomonov, MI 1973, Treasure of Saka, «Iskusstvo», Moscow). (in Rus).

Bejsenov 1997 - Bejsenov, AZ 1997, Pogrebal'nye pamyatniki i kul'tovo-ritual'nye sooruzheniya drevnikh nomadov TSentral'nogo Kazakhstana (7-1 vv. do n.eh.): avtoref. Dis. . kand. Ist. Nauk, Almaty. (Bejsenov, AZ 1997, Burial monuments and cult-ritual constructions of ancient nomads of the Central Kazakhstan (7-1 centuries BC): author. Dis. . kand. East. Sciences', Almaty). (in Rus).

Bejsenov, Dzhumabekova, Bazarbaeva 2015 - Bejsenov, AZ, Dzhumabekova, GS, Bazarbaeva, GA 2015, The Art of Saks Saryarka, Institut arkheologii im. A.KH. Margulana; "Begazy-Tasmola», Almaty, 168 p. (Bejsenov, AZ, Dzhumabekova, GS, Bazarbaeva, GA 2015, The Art of Saks Saryarka, Institut arkheologii im. A.KH. Margulana; «Begazy-Tasmola», Almaty, 168 p). (in Rus).

Bogdanov 1973 - Bogdanov, ES 1973, Obraz khishhnika v plasticheskom iskusstve kochevykh narodov TSentral'noj Azii (skifo-sibirskaya khudozhestvennaya traditsiya), IAEHT SO RAN, Novosibirsk. (Bogdanov, ES 1973, Image of predator in the plastic art of the nomadic peoples of Central Asia (Scythian-Siberian artistic tradition), IAEHT SO RAN, Novosibirsk). (in Rus).

CHugunov 2015 - Chugunov, KV 2015, Iskusstvo rannesakskogo vremeni tyvy i Kazakhstana:opyt sravnitel'nogo analiza i khronologiya, Sakskaya kul'tura Saryarki v kontekste izucheniya ehtnosotsiokul'turnykh protsessov Stepnoj Evrazii, NITSIA «Begazy-Tasmola», Almaty, 446 s. (Chugunov, KV 2015, art of the early Saka period of Tuva and Kazakhstan:experience of comparative analysis and chronology, Saka culture of Saryarka in the context of studying ethno-social processes of Eurasian Steppe, NITSIA «Begazy-Tasmola», Almaty, 446 p). (in Rus).

Pedracki Michal, Ajtbaev 2016 - Pedracki Michal, Ajtbaev, AB 2016, 2015 g. VostochnoKazakhstanskaya oblast'. Arkheologicheskie raskopki $v$ mogil'nike Kyrykungir, Altaj - tyrki әleminiң altyn besigi, Oskemen, 294 b. (Pedracki Michal, Ajtbaev, AB 2016, East Kazakhstan region. Archaeological excavations in the burial ground Karakuri, Altai-the Golden cradle of the Turkic world, Oskemen, 294 p). (in Rus).

Toleubaev 2013 - Toleubaev, AT 2013, Zolotye kurgany Shilikty, Kazakstan arkheologiyasynyn kola zhane erte temir dauiri maseleleri, Service Press, Almaty, 2013, 121 b. (Toleubaev, AT 2013, 
Golden mounds of Shilikta, Kazakhstan archeologiacal Ola and Early Iron age, Service Press, Almaty, 2013, 121 p). (in Rus).

Umitkaliev 2014 - Umitkaliev, UU 2014, Arkhitetura i semantika kurganov rannego zheleznogo veka, Metodologiya, metodika i praktika innovatsij. Integratsiya rossijskogo i zarubezhnogo opyta $v$ ehkonomike, proektnom menedzhmente obrazovanii, yurisprudentsii, yazykoznanii, kul'turologii $i$ dr 29-30 dekabrya 2014 goda. g. Sankt-Peterburg, Izd-vo «Kult'InformPress», Saint-Petersburg, S.135-139. (Umitkaliev, UU 2014, Architeture and semantics of the barrows of the early iron age, Methodology, methodology and practice of innovation. Integration of the Russian and foreign experience in Economics, project management, education, jurisprudence, linguistics, Culturology, etc 29-30 December 2014. Saint-Petersburg, Izd-vo «Kult'InformPress», Saint-Petersburg, P.135139). (in Rus). 